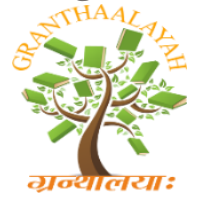

INTERNATIONAL JOURNAL OF RESEARCH GRANTHAALAYAH A knowledge Repository

\title{
THE ORIGIN OF INDIAN PAINTINGS AND THE EMERGENCE OF MINIATURE SCHOOLS OF PAINTING IN INDIA
}

\author{
Dr. Seema Tiwari ${ }^{* 1}$ \\ ${ }^{* 1}$ Professor Political Science, Government MLB Girls PG College, Indore, India
}

\begin{abstract}
Indian traditional art has always been rich in its types, forms and tecniques. Apart from the sculptures, poetry, textile arts, pottery, drama, dance, music etc., paintings are also an inextricable form of Indian art. The origin Indian art can be traced to ore-historic settlements in the 3rd millennium BC. The Indian art has undergone inevitable changes as a result of the influences of cultures, traditions, religions, religious sentiments, climatic conditions, globalisation and multiple other factors. Thus, with the development of the Indian civilization over the years developed the numerous kinds of paintings, as a means of communication, entertainment and livelihood. Being an important form of artistic expression, these paintings depict the life and customs followed by the people of different time periods.
\end{abstract}

Keywords: Origin; Paintings; Emergence; Miniature.

Cite This Article: Dr. Seema Tiwari. (2019). "THE ORIGIN OF INDIAN PAINTINGS AND THE EMERGENCE OF MINIATURE SCHOOLS OF PAINTING IN INDIA.” International Journal of Research - $\quad$ Granthaalayah, $7(11 \mathrm{SE}), \quad$ 146-149. https://doi.org/10.5281/zenodo.3585116.

The earliest Indian paintings were the rock paintings of prehistoric times. The evidence found by the archaeologists consists of carvings and drawings on cave rocks including those in Bhimbetka petroglyphs and in Ajanta and Ellora. The earliest known Indian art sculptures in the form of small terracotta and bronze figures depicting animals and humans etc. were produced by the people of Indus Valley Civilization. Thereafter, alongside the emergence and spread of religions like Hinduism and Buddhism, the Indian art started to be depicted in the form of sculptures of temples, deities and devotees and Greek influenced columns. This period was followed by the advent of Mughals and Britishers and their forms of art gained importance in India. The paintings usually featured mythological characters and animals which were being worshipped by the folklore. The British promoted European styles of art, leading to the merging of local art and foreign art. After the independence of India in 1947, new and contemporary styles of art and painting have gained importance, which still incorporate references to the prehistoric and medieval art culture of India.

One of the famous types of paintings which traces its origin in the Middle Kingdoms and Late Medieval Period (230 BCE - 1526 CE) is the Miniature Painting. These paintings were originated 
in India around 750 A.D. Miniatures are colourful handmade paintings which are very small in size, made with intricate brushwork. The colours used in the paintings were obtained from natural sources including vegetables, indigo, precious stones, gold and silver. The paintings were introduced in Eastern part of India where they were made on palm leaves and thus, had to be miniature in size because of the space constraints. Later on, around 960 A.D., such paintings also started to be appearing in Western parts is India, featuring religious themes. Further, the most common theme used in Indian miniature paintings is the Ragas or musical notes, religious stories and mythological stories. In the Mughal Empire, these paintings took a new form, one which was combined with Persian style of painting, and gave rise to the Mughal form of Miniature Paintings. Influenced by this, the Rajasthani Miniatures had their own distinct features, depicting the royal lifestyle and the stories of the bravery of Kings and Queens and also, the mythological tales of Lord Krishna. This development of Miniature Paintings can be classified into following Schools of Paintings -

\section{The Pala School of Painting}

This school dates back to the late eighth or mid-ninth century of the Pala period in the Eastern India. The paintings of this school mainly depicted the Buddhist yantras and symbols, portraying Buddhist deities. These paintings are characterised by sinuous line and subdued tones of colour. The art is still evident in the monasteries present in Nalanda, Vikramsila and Sompura and numerous other centres. It is a naturalistic style which resembles the ideal forms of contemporary bronze and stone sculpture, and reflects some feeling of the classical art of Ajanta. Over the years, this art spread across South-East, in places like Sri Lanka, Nepal, Burma and Tibet. When the Muslim invaders started destroying the Buddhist Monasteries, this art came to an abrupt end in Indi.

\section{The Western Indian School of Painting}

This style of painting prevailed in the present areas of Gujarat, Malwa and Rajasthan. The artistic paintings in the Western India were based on Jainism. The two popular Jain texts - The Kalpasutra and The Kalakacharya Katha - were repeatedly written and illustrated with paintings. The Kalpasutra of Bhadrabahu is the most popular among different paintings. These paintings feature exaggerations of physical characters of humans like eyes, hips and breasts, made in vigorous lines and forceful colours. The figures in the paintings also included lotuses and other flowers, birds and animals. The paintings were made in yellows and blues for clothes, black for hair and white for a representation of purity, all on a strong red background colour. Earlier, these depictions were made on palm leaves which were replaced by paper in the later years. The Jain Miniature style of painting spread all over India and also reached the temples of Pagan in Burma. The other living example of these paintings can also be found in Gita Govinda of Orissa.

\section{The Mughal School of Painting}

During the rule of Akbar and Jahangir, the Mughal School of miniature painting emerged. Under the supervision of two Persian masters, Mir Sayyed Ali and Abdul Samad Khan, an ateliar of painting was established. The Mughal school of painting was characterised by the Indian style of painting and the Safavid school of Persian painting. The Persian tradition is visible through the use 
of brilliant colors, elaborate embellishment of costumes and the lavish use of gold. Further, the Indian traits are noticeable in the gestures of hand and face, elongated eyes, long straight tree trunks, stylised trees and leaves, and also by the water surface covered with lotus flower or shown by zig-zag lines with a fish or two. These paintings depicted the scenes of warfare, hunting and trials of strength. Both the rulers encouraged the depictions of epics and histories, Ramayana, Mahabharata, Akbarnama and Hamzanama. Since Shah Jahan focussed more on Architecture rather than paintings, the miniature paintings, though better refined as compared to earlier periods, were not the centre of attraction. Later on, under the regime of Aurangzeb, the quality of the paintings declined and the painters moved to other areas, giving rise to other schools of miniature paintings.

\section{The Rajasthani School of Painting}

Deeply influenced by the Mughal Paintings, these paintings emerged in Rajputana, from Bikaner to the border of Gujarat and from Jodhpur to Gwalior and Ujjain. The main characteristics of these paintings were bold outlines and brilliant colours derived from natural sources like vegetables, conch shells, minerals, gold and silver. The Rajasthani Miniatures depicted subjects related to religion and love and court scenes. Each Rajasthani school of painting, like that in Bundi, Kota, Jaipur, Jodhpur and Kishangarh, has a unique and distinct style. The earliest evidence of Rajput painting belongs to the close of thirteenth century in the form of miniatures in a book Savaga Parikkmana Sutta Chuni, a Jaina scripture, illustrated in Mewar during the reign Rawal Tej Si. These paintings can be divided into two categories -first, the Jaipur Qalams, which provided shelter to a number of artists, and enabled them to develop a distinctive school or style of paintings and second, Kangra, the name drawn from a group of small states in the Punjab-Himalayan of which Kangra was the chief. This group developed a special style of its own. The difficult art of miniature painting still exists in Rajasthan where the painters often use paper, ivory and silk as their canvas. However, natural colors are no longer used as they have been replaced by artificial colors.

\section{The Pahari School of Painting}

The Pahari School of Miniature Painting emerged in the $17^{\text {th }}$ century A.D. This school was influenced by the Rajasthani School and the Mughal School in the usage of bold, contrasting colours and the use of highly decorated frames and borders respectively. The regions where these miniature paintings were prevalent included the present States of Himachal Pradesh, some areas of Punjab, Jammu and Garhwal in Uttar Pradesh. The Pahari School of Painting depicted lively and romantic themes and were characterized by soft tonal shading, exquisitely created backgrounds that merged with the theme, and attitudes and postures highly evocative of the moods they were to convey. The scenic beauty of the Himalayas was also often depicted in these paintings. These paintings gave rise to numerous other schools of paintings including the Guler School, Basohli School, Garhwal School, Chamba School and Kangra School.

\section{The Deccani School of Painting}

The Deccani painting school thrived from the late $16^{\text {th }}$ century among the Deccani sultanates in peninsular India, at Bijapur, Bijapur, Ahmadnagar, Golkonda and Hyderabad, the former states that formed the region known as Deccan. This school incorporates the elements of the Iranian, 
Ottoman, Arabian and South Indian paintings. These paintings are characterized by highly integrated blend of indigenous and foreign art forms, portraying intense colors and sensuous looking female figure and symmetrical arrangement. The ladies were portrayed with beautiful faces, large eyes and broad foreheads. The important colours used in making Deccani miniatures included bright red and orange. The artists majorly depicted geometrically accurate buildings and other wonders.

\section{The Company School of Painting}

This school of painting developed under the Britishers rule in India. The Company style is a term for a hybrid Indo-European style of paintings made in India by Indian and European artists, many of whom worked for European patrons in the British East India Company or other foreign Companies in the 18th and 19th centuries. The colonial rule introduced new styles, materials and techniques which were readily adopted by the local artists. The important developments were the idea of Realism and the technique of oil painting which helped the painters to produce images which looked real like a picturesque landscape painting. Unlike the existing Indian tradition of painting portraits in miniature, colonial portraits were life-size images that looked lifelike and real. This new style of portraiture also served as an ideal means of displaying the lavish lifestyles, wealth and status that the empire generated.

Apart from these, various other isolated Schools of Painting emerged in India. The Folk Paintings of India took the categories of Tribal Painting and Rural Painting. The Tribal Paintings included Bhil Paintings, Warli Paintings, Gond Paintings, Santhal Paintings, Saora Paintings and Kurumba Paintings. The Rural Paintings included Madhubani Paintings, Pattachitra Paintings, Kalamkari, Kolama and Mandana Paintings. The traditional Indian painting started deteriorating after the first half of the 18th century and by the end of the century it lost most of its vitality and charm. However, in the Pahari region the art of painting maintained its quality till the end of the first quarter of the 19th century. Under the impact of the Western colours and technique of painting the traditional styles of Indian painting finally died out in the second half of the 19th century.

The modern and contemporary art feature a certain freedom from invention, the acceptance of an eclectic approach which has placed artistic expression in the international perspective as against the regional, a positive elevation of technique which has become both proliferous and supreme, and the emergence of the artist as a distinct individual. The Oil Paintings made by Raja Ravi Varma depicted mythological and social themes and provided a link between the traditional Indian art and the contemporary art. The rich traditional painting culture will always find its survival and reference in the Contemporary Indian Paintings. 